\title{
Effect of different levels of customized fertilizer on soil nutrient availability, yield and economics of onion
}

\section{B. M. Kamble* and D. K. Kathmale}

Department of Soil Science and Agricultural Chemistry, Agricultural Research Station, Kasabe Digraj, Sangli- 416305(Maharashtra), INDIA

*Corresponding author. Email: bmkamble2007@rediffmail.com

Received: March 18, 2015; Revised received: August 12, 2015; Accepted: October 12, 2015

Abstract: A field experiment was conducted to study the effect of different levels of customized fertilizer (CF) on soil nutrient availability, yield and economics of onion. The results revealed that the significantly highest plant height $(57.77 \mathrm{~cm})$, stem diameter $(6.03 \mathrm{~cm})$ and bulb diameter $(15.13 \mathrm{~cm})$ at the time of harvest, fertilizer use efficiency,bulb yield $\left(22.34 \mathrm{t} \mathrm{ha}^{-1}\right)$ and benefit:cost ratio (2.56) of onion were recorded in $100 \%$ recommended dose of NPK through CF in three equal split doses. The significantly highest available nitrogen $\left(213 \mathrm{~kg} \mathrm{ha}^{-1}\right)$, phosphorus (14.42 $\mathrm{kg} \mathrm{ha}^{-1}$ ) were recorded in $125 \%$ recommended dose of NPK through CF in two equal split doses and available K $\left(804 \mathrm{~kg} \mathrm{ha}^{-1}\right)$ in $100 \%$ recommended dose of NPK through CF in three equal split doses over the rest of the other treatments. The application of $100 \%$ recommended dose of fertilizer (100:50:50 N: $\left.\mathrm{P}_{2} \mathrm{O}_{5}: \mathrm{K}_{2} \mathrm{O} \mathrm{kg} \mathrm{ha}^{-1}\right)$ either two or three splits through CF to onion appears to be improving soil fertility, yield and yield contributing character of onion and getting higher net monetary returns.

Keywords: Economics of onion, Effect of customized fertilizer levels, Nutrient availability of soil.

\section{INTRODUCTION}

Onion (Allium cepa L.) is one of the important vegetable crops in India. It is a rich in sulphur containing compounds that are responsible for their pungent odours (Bankole et al., 2004). Onion bulb is a rich source of minerals like phosphorus and calcium. It also contains protein and vitamin C. Onions contain quercetin, a flavonoid. Quercetin helps to eliminate free radicals in the human body, to inhibit low density lipoprotein oxidation (an important reaction in the atherosclerosis and coronary heart disease), to protect and regenerate vitamin $\mathrm{E}$ and to inactivate the harmful effects of chelate metal ions (Grubben and Denton, 2004; Scott, 2007). Onions are now being used in several ways as in fresh, frozen, canned, caramelized, pickled, powdered, chopped and dehydrated forms. Onion powder is a spice used for seasoning in cooking (Jilanil et al., 2004).

India is the second largest producer of onion in the world, next only to China. In India, onion is being grown in an area of 1.05 million hectares with production of 16.81 million tonnes and the productivity is low $14.85 \mathrm{t} \mathrm{ha}^{-1}$. Maharashtra is the leading onion producing state followed by Karnataka, Rajasthan etc. In Maharashtra, onion is cultivated in an area of 2.60 lakh hectares with production of 46.60 lakh tonnes and the average productivity is 17.92 $\mathrm{t} \mathrm{ha}^{-1}$ in the year 2012-13 (Anonymous, 2014) which is low compared to world average. In onion, nutrient is the main limiting factor for low productivity. Fertilizer application to crop plants had been to provide nutrients to plants and in turn obtain enhanced or sustained optimal yield and hence the fertilizer producers and users had been and are being attempting to improve fertilizer use efficiency in terms of nutrient uptake and crop yield. It has been realized that the excessive use of inorganic fertilizers, which is the common agricultural practice of green revolution, is not a sustainable farming practice from either economic or ecological point of view. The continued use of chemical fertilizers causes health and environmental hazards such as ground and surface water pollution by nitrate leaching and surface runoff (Pimentel, 1996). The excessive fertilizer applications as well as inadequate timing of application lead to fertilizer loss. Reduction in pre-plant fertilizer and split applications to better match nutrient availability in the soil with the plants nutrient demand would help reduce the fertilizer loss. Split application of fertilizer reduces the risk of nutrient loss (Sanchez and Doerge, 1999). The combined effect of different levels of potassium and its application methods was statistically significant like three split application of $120 \mathrm{~kg} \mathrm{ha} \mathrm{ha}^{-1}$ potassium gave the highest bulb yield (Islam et al., 2008). Customized fertilizers are multi-nutrient carrier designed to contain macro and micro nutrients. Use of customized fertilizers promotes site specific nutrient management so as to achieve maximum use efficiency of applied nutrients in a cost effective manner. In view to above, the 
present investigation was undertaken to study the effect of different levels of customized fertilizer on soil nutrient availability, economics, yield and yield contributing characters of onion.

\section{MATERIALS AND METHODS}

The field experiment was conducted during rabi 2013 at Agricultural Research Station, Kasabe Digraj, District-Sangli (M.S.) India to study the effect of different levels of customized fertilizer on soil nutrient availability, yield and economics of onion. The experimental initial soil status was $\mathrm{pH} 8.27$, EC $0.27 \mathrm{dS} \mathrm{m}^{-1}$, available $\mathrm{N} 178 \mathrm{~kg} \mathrm{ha}^{-1}, \mathrm{P} 10.50 \mathrm{~kg} \mathrm{ha}^{-1}$ and $\mathrm{K} 732 \mathrm{~kg}$ $\mathrm{ha}^{-1}$.The field experiment was laid out in a randomized block design with eight treatments and replicated in three times. The treatments were $\mathrm{T}_{1}$-Absolute control, $T_{2}-100 \%$ recommended dose of fertilizer (RD), $T_{3}$ $-75 \%$ RD of NPK through customized fertilizer in two equal split doses $\{(50 \%$ at basal $+50 \%$ at 30 days after transplanting (DAT) $\}, \mathrm{T}_{4}-100 \% \mathrm{RD}$ of NPK through customized fertilizer in two equal split doses $(50 \%$ at basal $+50 \%$ at $30 \mathrm{DAT}), \mathrm{T}_{5}-125 \% \mathrm{RD}$ of NPK through customized fertilizer in two equal split doses $(50 \%$ at basal $+50 \%$ at $30 \mathrm{DAT}), \mathrm{T}_{6}-75 \% \mathrm{RD}$ of NPK through customized fertilizer in three equal split doses (33\% at basal, 30 and 60 DAT), $\mathrm{T}_{7}-100 \%$ RD of NPK through customized fertilizer in three equal split doses (33\% at basal, 30 and 60 DAT) and $\mathrm{T}_{8}-125 \%$ RDF of NPK through customized fertilizer in three equal split doses (33\% at basal, 30 and 60 DAT). The recommended dose of fertilizer (RDF) was applied for onion (100:50:50 N: $\left.\mathrm{P}_{2} 0_{5}: \mathrm{K}_{2} \mathrm{O} \mathrm{kg} \mathrm{ha}{ }^{-1}\right)$ as per the treatments. The onion (cv. Phule Samarth) was transplanted on spacing at $15 \times 10 \mathrm{~cm}^{2}$. The customized fertilizer was obtained from the Rashtriya Chemicals and fertilizers Ltd, Mahul Road, Chembur, Mumbai (M.S.) which was having characters viz., N $20 \%$, P 12 $\%$, K $10 \%$, S $4.0 \%$, Mg $0.25 \%$, Zn $0.50 \%$ and Fe $0.50 \%$ and applied as per treatments. The data of growth and bulb yield of onion were recorded at the time of harvest. The standard agronomic packages of practices were adopted for onion crop. The soil samples were collected from each plot at the time of onion harvest and air dried and pulverized to pass through 2 $\mathrm{mm}$ sieve for general analysis. These soil samples were analysed for various chemical properties. The $\mathrm{pH}$ (1:2.5) and EC of soil were determined by $\mathrm{pH}$ meter and conductivity meter (Jackson, 1973). The soil samples were analysed for available $\mathrm{N}$ by the alkaline permanganate method (Subbiah and Asija, 1956), availble $\mathrm{P}$ (Olsen- P) by $0.5 \mathrm{M} \mathrm{NaHCO}_{3}$ extraction (Olsen et al., 1954), available $\mathrm{K}\left(\mathrm{NH}_{4} \mathrm{OAc}\right)$ by $1 \mathrm{~N}$ neutral $\mathrm{NH}_{4} \mathrm{OAc}$ extraction on flame photometer (Knudsen et al., 1982) and DTPA extractable micronutrients (Fe, $\mathrm{Mn}, \mathrm{Cu}$ and $\mathrm{Zn}$ ) by Lindsay and Norvell (1978). The statistical analysis of the data was carried out by using standard statistical method of analysis of variance (Panse and Sukhatme, 1985).

\section{RESULTS AND DISCUSSION}

Yield and yield contributing characters: The yield contributing characters of onion at the time of harvest i.e. height of plant, stem diameter and bulb diameter were found significant effect due to the different levels of customized fertilizer (CF) (Table 1). The significantly highest height of plant $(57.77 \mathrm{~cm})$, stem diameter $(6.03 \mathrm{~cm})$ and bulb diameter $(15.13 \mathrm{~cm})$ at the time of harvest were recorded in $T_{1}$ over the rest of the other treatments. The treatments $\mathrm{T}_{2}, \mathrm{~T}_{4}, \mathrm{~T}_{5}, \mathrm{~T}_{7}$ and $\mathrm{T}_{8}$ were at par with each other for plant height, stem and bulb diameter. The increase in plant height, stem diameter and bulb diameter with the addition of NPK through CF may be attributed to more availability of nutrients, especially $\mathrm{N}$, which enhances the number of leaves by its simulative effect on cell division and cell enlargement that in turn may increase number of leaves and leaf dimensions. Three nitrogen levels (50, $75,100 \mathrm{~kg} \mathrm{ha}^{-1}$ ) and its three methods of application (basal, top-dressing and foliar spray) affected bulb yield significantly in onion (Tiwari et al., 2002). AlAbdulsalam and Hamaiel (2004) stated that potassium application increase the efficiency of plant for utilization of nitrogen that enhances the plant growth. Nasreen et al., (2007) reported that the addition of nitrogen and sulphur fertilizers exerted significant influence on the number of leaves/plant, plant height, diameter of bulb, single bulb weight, and yield of onion. The lowest height of plant, stem diameter and bulb diameter were recorded in treatment $\mathrm{T}_{1}$ i.e. absolute control. The significant effect on bulb and green leaves yield of onion was recorded due to the effect of different levels of CF (Table 1). The highest bulb yield of onion $\left(22.34 \mathrm{t} \mathrm{ha}^{-1}\right)$ was recorded in $\mathrm{T}_{7}$ over the rest of the other treatments. The treatment $T_{7}$ was at par with treatments $T_{4}, T_{5}$, and $T_{6}$. The highest green leaves yield of onion (13.02 $\mathrm{t} \mathrm{ha}^{-1}$ ) was recorded in $\mathrm{T}_{4}$ over the rest of the other treatments and this treatment was at par with remaining all the treatments except $T_{1}$. The increase in yield might be due to applying nitrogen improving the vegetative growth and and increase in net assimilation rate and accelerating the photosythates in storage organs of bulbs resulting in an increased diameter and weight of the bulb (Sharma, 1992). Rahim et al., (1992) and Al-Moshileh (2001) have also reported a significant interaction of nitrogen and phosphorus on growth and yield of onion. Nasreen et al., (2007) reported that the addition of nitrogen and sulphur fertilizers exerted significant influence on the number of leaves/plant, plant height, diameter of bulb, single bulb weight and yield of onion. Ali et al., (2007) reported that bulb diameter of onion crop is positively affected by potassium, the bulb diameter increases with increases potash levels. The application of CF in two and three split application to onion increased nutrient availability and ultimately increased bulb yield of onion. The splitting $250 \mathrm{~kg} \mathrm{~N} \mathrm{ha}{ }^{-1}$ into two applications provided greater grain yield than a single 
Table 1. Effect of different levels of customized fertilizer on yield and yield contributing characters of onion at harvest.

\begin{tabular}{|c|c|c|c|c|c|c|}
\hline Treatments & $\begin{array}{l}\text { Height of } \\
\text { plant (cm) }\end{array}$ & $\begin{array}{c}\text { Stem } \\
\text { diameter } \\
(\mathrm{cm})\end{array}$ & $\begin{array}{c}\text { Bulb } \\
\text { diameter } \\
(\mathrm{cm})\end{array}$ & $\begin{array}{c}\text { Onion bulb } \\
\text { yield } \\
\left(\mathrm{t} \mathrm{h \textrm {h } ^ { - 1 }}\right)\end{array}$ & $\begin{array}{c}\text { Green leaves } \\
\text { yield } \\
\left(\mathbf{t ~ h a}^{-1}\right)\end{array}$ & $\begin{array}{c}\text { FUE } \\
\text { (kg bulb/ } \\
\text { kg fertil- } \\
\text { izer) }\end{array}$ \\
\hline $\mathrm{T}_{1-\text { Control }}$ & 47.77 & 4.63 & 10.85 & 13.89 & 8.97 & - \\
\hline $\mathrm{T}_{2}-100 \% \mathrm{RDF}$ & 53.27 & 5.58 & 14.68 & 19.19 & 12.05 & 19.12 \\
\hline $\begin{array}{l}\mathrm{T}_{3}-75 \% \mathrm{RD} \text { of NPK through } \mathrm{CF} \\
\text { ( } 2 \text { equal doses) }\end{array}$ & 51.80 & 5.47 & 12.97 & 17.28 & 12.17 & 17.18 \\
\hline $\begin{array}{l}\mathrm{T}_{4}-100 \% \mathrm{RD} \text { of NPK through } \mathrm{CF} \\
\text { ( } 2 \text { equal doses) }\end{array}$ & 56.80 & 5.63 & 14.25 & 21.96 & 13.02 & 21.89 \\
\hline $\begin{array}{l}\mathrm{T}_{5}-125 \% \text { RD of NPK through } \mathrm{CF} \\
\text { ( } 2 \text { equal doses) }\end{array}$ & 55.40 & 5.47 & 14.35 & 20.91 & 12.16 & 19.85 \\
\hline $\begin{array}{l}\mathrm{T}_{6}-75 \% \text { RD of NPK through } \mathrm{CF} \\
\text { ( } 3 \text { equal doses) }\end{array}$ & 54.94 & 5.53 & 13.40 & 19.61 & 12.82 & 19.52 \\
\hline $\begin{array}{l}\mathrm{T}_{7}-100 \% \mathrm{RD} \text { of NPK through } \mathrm{CF} \\
\text { ( } 3 \text { equal doses) }\end{array}$ & 57.77 & 6.03 & 15.13 & 22.34 & 12.61 & 22.27 \\
\hline $\begin{array}{l}\mathrm{T}_{8}-125 \% \mathrm{RD} \text { of NPK through } \mathrm{CF} \\
\text { ( } 3 \text { equal doses) }\end{array}$ & 57.67 & 5.87 & 14.49 & 20.23 & 12.20 & 19.17 \\
\hline Mean & 54.43 & 5.53 & 13.76 & 19.38 & 12.00 & 19.86 \\
\hline S.E.+/- & 1.78 & 0.39 & 0.81 & 0.93 & 0.70 & 0.96 \\
\hline C.D. at $5 \%$ & 5.40 & 1.17 & 2.44 & 2.83 & 2.12 & 2.96 \\
\hline
\end{tabular}

application of $\mathrm{N}$ at the same rate (Gehl et al.,2005). The lowest bulb and green leaves yield of onion were observed in treatment in $\mathrm{T}_{1}$ i.e. absolute control. The highest fertilizer use efficiency was recorded in $\mathrm{T}_{7}$ over the rest of the other treatments, this might be due to split applications of fertilizer and a postponed basal application reduced nutrient loss through leaching (Sitthaphanit et al., 2009).

Soil nutrient availability status: The effect of different levels of CF was found significant effect on soil electrical conductivity, available $\mathrm{N}, \mathrm{P}$ and $\mathrm{K}$ after harvest of onion (Table 2). The non significant effect was showed on soil $\mathrm{pH}$ might be due to high buffering capacity to clay soil and nominal presence of any weak salts namely carbonates or bicarbonates, which on dissolution release free cations might be the possible causes for the stability of the soil reaction. The significantly highest available $\mathrm{N}\left(213 \mathrm{~kg} \mathrm{ha}^{-1}\right), \mathrm{P}(14.42 \mathrm{~kg}$ ha ${ }^{-1}$ ) were recorded by treatment $\mathrm{T}_{5}$ and available $\mathrm{K}(804$ $\left.\mathrm{kg} \mathrm{ha}^{-1}\right)$ in $\mathrm{T}_{4}$ over the rest of the other treatments. The treatments $\mathrm{T}_{4}, \mathrm{~T}_{5}, \mathrm{~T}_{6}, \mathrm{~T}_{7}$, and $\mathrm{T}_{8}$ were at par with each other for available $\mathrm{N}, \mathrm{P}$ and $\mathrm{K}$. The more availability of nutrients was found due to the addition of NPK through CF in two or three split application. N, P and $\mathrm{K}$ availability in soil increased with each increment of fertilizer dose through $\mathrm{CF}$ and as compare to one time application (RD-NPK). However, increase in availability was not proportionate to added amount. Nutrient availability in soil also increased with advancement in crop age due to split application of CF. Plant roots excretes organic acids and chelating organic compounds in rhizosphere. These compounds form multiple complex compounds with $\mathrm{Ca}, \mathrm{Mg}$ and/or $\mathrm{Fe}$ and thereby increased phosphorus availability in soil (Tinker, 1980). Increased availabilities of N, P, and K may also result from changes in soil nutrient turnover rates due to altered ecosystem properties. Soil nutrient turnover rate consist of decomposition, mineralization, weathering, chemical complexation, adsorption or nutrient uptake by crops and soil organisms (Mengel, 1982; Wallbridge and Vitousek,1987; Marrs, 1993). The lowest available $\mathrm{N}, \mathrm{P}$ and $\mathrm{K}$ were recorded in treatment $\mathrm{T}_{1}$. The effect of different levels of CF on DTPA micronutrient viz; $\mathrm{Fe}, \mathrm{Zn}, \mathrm{Mn}$ and $\mathrm{Cu}$ showed non significant effect (Table 3). The highest DTPA micronutrient viz; Fe, Zn, $\mathrm{Mn}$ and $\mathrm{Cu}$ in soil after harvest of onion were recorded in $\mathrm{T}_{7}$ over the rest of the other treatments. The application of fertilizer through $\mathrm{CF}$ increased the micronutrient content in soil might be due to CF contains micronutrients and less fixation in soil because of split application. The lowest Fe, $\mathrm{Zn}, \mathrm{Mn}$ and $\mathrm{Cu}$ in soil were recorded in treatment $\mathrm{T}_{1}$.

Economics of onion: The highest gross returns (178738 Rs. ha ${ }^{-1}$ ), net returns (108831 Rs. ha ${ }^{-1}$ ) and B:C ratio (2.56) of onion were recorded in $\mathrm{T}_{7}$ as compare to other treatments and it at par with treatment $T_{4}$ for net returns and $\mathrm{B}: \mathrm{C}$ ratio (Table 4). This might be due to higher bulb yield of onion crop was obtained in these treatments as compared to other treatments. The lowest gross returns (111116 Rs. ha ${ }^{-1}$ ), net returns (45209 Rs.ha ${ }^{-1}$ ) and B:C ratio (1.69) of onion were recorded in $\left(\mathrm{T}_{1}\right)$ control.

\section{Conclusion}

On the basis of this study it was concluded that the application of $100 \%$ recommended dose of fertilizer (100:50:50 N: $\mathrm{P}_{2} \mathrm{O}_{5}: \mathrm{K}_{2} 0 \mathrm{~kg} \mathrm{ha}^{-1}$ ) through customized fertilizer in either two or three splits to onion crop can be recommended for getting higher net monetary returns, bulb yield and improvement of soil fertility.

\section{REFERENCES}

Al-Abdulsalam, M. A. and Hamaiel, A. F. (2004). Effect of planting dates and compound fertilizers on growth, yield and quality of Hassawi onion under Al-Hassa oasis. Science Journal of King Faisal University, 5 (1): 65-79. 
Table 2. Effect of different levels of customized fertilizer on soil properties and available nutrient status after harvest of onion.

\begin{tabular}{|c|c|c|c|c|c|}
\hline \multirow[b]{2}{*}{ Treatments } & \multicolumn{2}{|c|}{ Soil properties } & \multicolumn{2}{|c|}{ Available nutrient status } & \multirow{2}{*}{$\frac{\left(\mathrm{kg} \mathrm{ha}^{-1}\right)}{\mathrm{K}}$} \\
\hline & $\mathrm{pH}$ & $\begin{array}{c}\mathbf{E C} \\
\left(\mathrm{dS} \mathrm{m}^{-1}\right)\end{array}$ & $\mathbf{N}$ & $\mathbf{P}$ & \\
\hline Initial & 8.27 & 0.27 & 178 & 10.50 & 732 \\
\hline $\mathrm{T}_{1}$ Control & 8.30 & 0.28 & 169 & 9.79 & 653 \\
\hline $\mathrm{T}_{2}-100 \% \mathrm{RDF}$ & 8.10 & 0.44 & 179 & 10.90 & 750 \\
\hline $\begin{array}{l}\mathrm{T}_{3}-75 \% \mathrm{RD} \text { of NPK through } \mathrm{CF} \\
\text { (2 equal doses) }\end{array}$ & 8.07 & 0.48 & 182 & 13.17 & 762 \\
\hline $\begin{array}{l}\mathrm{T}_{4}-100 \% \mathrm{RD} \text { of } \mathrm{NPK} \text { through } \mathrm{CF} \\
\text { (2 equal doses) }\end{array}$ & 8.03 & 0.50 & 199 & 13.92 & 773 \\
\hline $\begin{array}{l}\mathrm{T}_{5}-125 \% \mathrm{RD} \text { of NPK through } \mathrm{CF} \\
\text { ( } 2 \text { equal doses) }\end{array}$ & 8.03 & 0.55 & 213 & 14.42 & 796 \\
\hline $\begin{array}{l}\mathrm{T}_{6}-75 \% \mathrm{RD} \text { of } \mathrm{NPK} \text { through } \mathrm{CF} \\
\text { (3 equal doses) }\end{array}$ & 8.03 & 0.51 & 185 & 12.88 & 757 \\
\hline $\begin{array}{l}\mathrm{T}_{7}-100 \% \mathrm{RD} \text { of } \mathrm{NPK} \text { through } \mathrm{CF} \\
\text { (3 equal doses) }\end{array}$ & 7.97 & 0.52 & 210 & 14.12 & 804 \\
\hline $\begin{array}{l}\mathrm{T}_{8}-125 \% \mathrm{RD} \text { of } \mathrm{NPK} \text { through } \mathrm{CF} \\
\text { (3 equal doses) }\end{array}$ & 8.07 & 0.54 & 212 & 14.09 & 802 \\
\hline S.E.+/- & 0.08 & 0.04 & 6.3 & 0.97 & 23 \\
\hline C.D. at $5 \%$ & NS & 0.11 & 19.1 & 2.95 & 71 \\
\hline
\end{tabular}

Table 3. Effect of different levels of customized fertilizer on DTPA micronutrients after harvest of onion.

\begin{tabular}{|c|c|c|c|c|}
\hline \multirow{2}{*}{ Treatments } & \multicolumn{4}{|c|}{ DTPA micronutrient (ppm) } \\
\hline & $\mathbf{F e}$ & $\mathrm{Zn}$ & Mn & $\mathbf{C u}$ \\
\hline Initial & 4.03 & 0.28 & 4.95 & 2.15 \\
\hline $\mathrm{T}_{1-}$ Control & 3.68 & 0.35 & 4.75 & 2.01 \\
\hline $\mathrm{T}_{2}-100 \% \mathrm{RDF}$ & 3.91 & 0.37 & 4.99 & 2.18 \\
\hline $\begin{array}{l}\mathrm{T}_{3}-75 \% \mathrm{RD} \text { of } \mathrm{NPK} \text { through } \mathrm{CF} \\
\text { ( } 2 \text { equal doses) }\end{array}$ & 4.03 & 0.42 & 5.13 & 2.32 \\
\hline $\begin{array}{l}\mathrm{T}_{4}-100 \% \mathrm{RD} \text { of NPK through } \mathrm{CF} \\
\text { ( } 2 \text { equal doses) }\end{array}$ & 4.16 & 0.47 & 5.16 & 2.33 \\
\hline $\begin{array}{l}\mathrm{T}_{5}-125 \% \mathrm{RD} \text { of NPK through } \mathrm{CF} \\
\text { (2 equal doses) }\end{array}$ & 4.15 & 0.45 & 5.11 & 2.27 \\
\hline $\begin{array}{l}\mathrm{T}_{6}-75 \% \mathrm{RD} \text { of NPK through } \mathrm{CF} \\
\text { (3 equal doses) }\end{array}$ & 4.09 & 0.43 & 5.06 & 2.21 \\
\hline $\begin{array}{l}\mathrm{T}_{7}-100 \% \mathrm{RD} \text { of NPK through } \mathrm{CF} \\
\text { (3 equal doses) }\end{array}$ & 4.17 & 0.48 & 5.17 & 2.34 \\
\hline $\begin{array}{l}\mathrm{T}_{8}-125 \% \mathrm{RD} \text { of } \mathrm{NPK} \text { through } \mathrm{CF} \\
\text { (3 equal doses) }\end{array}$ & 4.16 & 0.47 & 5.10 & 2.24 \\
\hline S.E.+/- & 0.10 & 0.05 & 0.22 & 0.09 \\
\hline C.D. at $5 \%$ & NS & NS & NS & NS \\
\hline
\end{tabular}

Table 4. Effect of different levels of customized fertilizer on economics of onion.

\begin{tabular}{|c|c|c|c|c|}
\hline Treatments & $\begin{array}{c}\text { Gross Re- } \\
\text { turns } \\
\left(\text { Rs. ha }^{-1}\right) \\
\end{array}$ & $\begin{array}{c}\text { Cost of cultiva- } \\
\text { tion } \\
\left(\text { Rs. ha }^{-1}\right) \\
\end{array}$ & $\begin{array}{l}\text { Net Returns } \\
\left(\text { Rs. ha' }{ }^{-1}\right)\end{array}$ & $\begin{array}{c}\text { B:C } \\
\text { Ratio }\end{array}$ \\
\hline $\mathrm{T}_{1-}$ Control & 111116 & 65907 & 45209 & 1.69 \\
\hline $\mathrm{T}_{2}-100 \% \mathrm{RDF}$ & 153534 & 69907 & 83627 & 2.20 \\
\hline $\begin{array}{l}\mathrm{T}_{3}-75 \% \mathrm{RD} \text { of NPK through } \mathrm{CF} \\
\text { ( } 2 \text { equal doses) }\end{array}$ & 138220 & 68907 & 69313 & 2.01 \\
\hline $\begin{array}{l}\mathrm{T}_{4}-100 \% \mathrm{RD} \text { of } \mathrm{NPK} \text { through } \mathrm{CF} \\
\text { (2 equal doses) }\end{array}$ & 175680 & 69907 & 105773 & 2.51 \\
\hline $\begin{array}{l}\mathrm{T}_{5}-125 \% \mathrm{RD} \text { of } \mathrm{NPK} \text { through } \mathrm{CF} \\
\text { (2 equal doses) }\end{array}$ & 159258 & 70907 & 88351 & 2.25 \\
\hline $\begin{array}{l}\mathrm{T}_{6}-75 \% \mathrm{RD} \text { of } \mathrm{NPK} \text { through } \mathrm{CF} \\
\text { (3 equal doses) }\end{array}$ & 156886 & 68907 & 87979 & 2.28 \\
\hline $\begin{array}{l}\mathrm{T}_{7}-100 \% \mathrm{RD} \text { of } \mathrm{NPK} \text { through } \mathrm{CF} \\
\text { ( } 3 \text { equal doses) }\end{array}$ & 178738 & 69907 & 108831 & 2.56 \\
\hline $\begin{array}{l}\mathrm{T}_{8}-125 \% \mathrm{RD} \text { of } \mathrm{NPK} \text { through } \mathrm{CF} \\
\text { (3 equal doses) }\end{array}$ & 153823 & 70907 & 82916 & 2.17 \\
\hline S.E.+/- & & & 7465 & 0.11 \\
\hline C.D. at $5 \%$ & & & 22646 & 0.33 \\
\hline
\end{tabular}


Ali, M. K., Alam, M. F., Alam, M. N., Islam, M. S. and Khandaker, S. M. A. T. (2007). Effect of nitrogen and potassium level on yield and quality seed production of onion. Journal of Applied Science and Research, 3 (12): 1889-1899.

Al-Moshileh, A.M. (2001). Effect of nitrogen, phosphorus and potassium fertilizer on onion productivity in central region of Saudi Arabia. Assist Journal of Horticulture Science, $32: 291-305$.

Anonymous (2014). National Horticultural Board, (http:// nhb.gov.in / area\% production, html).

Bankole, S.A., Ogunsanwo, B.M. and Mabekoje, O.O. (2004). Natural occurrence of moulds and aflatoxin B1 in melon seeds from markets in Nigeria. Food Chemistry and Toxicology, 42: 1309-1314.

Gehl, R. J., Schmidt, J.P., Maddux, L.D. and Gordon, W.B. (2005). Corn yield response to nitrogen rate and timing in sandy irrigated soils. Agronomy Journal, 97: 1230-1238.

Grubben, G.J.H and Denton, D.A. (2004). Plant resources of Tropical Africa 2- Vegetables. PROTA Foundation, Wageningen, Bacjhugs, leiden CTA Wageingen.

Islam, M.A., Shamsuddoha, A.T.M., Bhuiyan, S.I. and Mirza Hasanuzzaman. (2008). Response of summer onion to potash and its application methods. American-Eurasian Journal of Agronomy, 1 (1) : 10-15.

Jackson, M.L. (1973). Soil Chemical Analysis. New Delhi : Prentice Hall of India Pvt. Ltd.

Jilanil, M.S., Ghaffoor, A., Waseem, K. and Farooq, J.I. (2004). Effect of different levels of nitrogen on growth and yield of three Onion varieties. International Journal of Agriculture and Biology, 6(3): 507-510.

Knudsen, D., Peterson, G.A. and Pratt, P.F. (1982). Lithium, sodium and potassium. In: Methods of Soil Analysis Part 2. Chemical and microbiological properties second edition. ed. A. L. Page, R.H. Miller and D.R. Keeney, pp. 225-246. Agron. Monograph No.9, Am. Soc. of Agron. Inc., Soil Sci. Soc. Am. Inc., Madison, Wisconsin, USA.

Lindsay, W.L. and Norvell, W.A. (1978). Development of DTPA soil test for zinc, iron, manganese and copper. Soil Science America Journal, 42: 421-428.

Marrs, R. H. (1993). Soil fertility and nature conservation in Europe: theoretical considerations and practical management solutions. Advances in Ecological Research, 24:241-300.

Mengel, K. (1982). Dynamics and availability of major nutrients in soils. Advances in Soil Science, $2: 65-131$.

Nasreen,S., Haque, M. M., Hossain, M. A. and Farid, A. T.
M. (2007). Nutrient uptake and yield of onion as influenced by nitrogen and sulphur fertilization. Bangladesh Journal of Agricultural Research, 32 (3) : 413-420.

Olsen, S. R., Coles, C.V., Watanabe, F.S. and Dean, L. N. (1954). Estimation of available phosphorus in soils by extraction with sodium bicarbonate. USDA Circular 939.

Panse, V.G. and Sukhatme, P.V. (1985). Statistical method of Agricultural workers. ICAR, New Delhi. pp. 143147.

Pimentel, D. (1996). Green revolution and chemical hazards. Science of Total Environment, $188: 86-98$.

Rahim, M.A., Bashar, M.A., Begun, A. and Hakim, M.A. (1992). Onion storage in Bangaladesh. Onion Newsletter for the Tropics, 4: 55-56.

Sanchez, C.A. and Doerge, T. A. (1999). Using nutrient uptake patterns to develop efficient nitrogen management strategies for vegetables. Horticulture Technology, 9 (4): 601-606.

Scott, T. (2007). What is the chemical process that causes my eyes to tear when I peel an onion? Ask the expert; Chemistry Scientific American. Retrieved on 8th April, 2007.

Sharma, R.P. (1992). Effect of planting material, nitrogen and potash on bulb yield of rainy season onion (Allium cepa L.). Indian Journal of Agronomy, 37 : 868-869.

Sitthaphanit, S., Limpinuntana, V., Toomsan, B., Panchaban, S. and Bell, R.W. (2009). Fertilizer strategies for improved nutrient use efficiency on sandy soils in high rainfall regimes. Nutrient Cycling Agroecosystem, 85: 123-139.

Subbiah, B.V. and Asija, G.L. (1956). A rapid procedure for the estimation of available nitrogen in soils. Current Science, $25: 259-260$.

Tinker, P.B. (1980). Role of rhizosphere microorganisms in phosphorus uptake by plants, In: R.C. Dinauer (Ed.), The Role of Phosphorus in Agriculture, ASA-CSSASSSA, Madison, WI, USA.

Tiwari, R.S., Ankur, A. and Sengar, S.C. (2002). Effect of doses and methods of nitrogen application on growth, bulb yield and quality of "Pusa Red" onion (Allium cepa). Indian Journal of Agriculture Sciences, 72 (1): 23-25.

Walbridge, M. R. and Vitousek, P.M. (1987). Phosphorus mineralization potentials in acid organic soil: processes affecting ${ }^{32} \mathrm{PO}_{4}{ }^{3-}$ isotope dilution measurements. Soil Biology and Biochemistry, 19: 709-717. 